\title{
KNOWLEDGE OF BREAST SELF-EXAMINATION AMONG WOMEN WITH TEENAGE DAUGHTERS
}

\author{
Dewi Andriani ${ }^{1}$, Restuning Widiasih ${ }^{2}$, Citra Windani Mambang $\mathrm{S}^{3}$ \\ ${ }^{123}$ Faculty of Nursing, Universitas Padjadjaran \\ Corresponding email : restuning.widiasih@unpad.ac.id
}

\begin{abstract}
Background, the incidence of breast cancer in women increases every year worldwide including Indonesia. Breast Self-Examination (BSE) is an early detection method for detecting breast cancer that can be done by all women. However, research in Indonesia that examines women's knowledge about BSE, especially in women who have teenage daughters is limited. The purpose of this study was to identify women's knowledge about BSE, especially women with teenage daughters. Method, This study was quantitative descriptive research. The samples were selected using the total sampling technique. The number of samples was 138 women who have teenage daughters. This study was conducted in Sarijadi Village, Bandung. The research instrument was a knowledge questionnaire about BSE. Data were analyzed using frequency distribution. The results of the study, women had a moderate level of knowledge about BSE (51.4\%) Women's knowledge was good in the component of purposes and benefits of the BSE (79.7\%), and they had poor understanding related to identifying sources to conduct BSE to their daughters (73.2\%), Conclusions and recommendation, women have good knowledge about the purposes and benefits of BSE, however they had lack of knowledge about the role of women in supporting girls to conduct BSE. Women need information from health workers relates to their roles in conducting BSE to their daughters. Further research is needed to examine the knowledge and role of fathers in women's health especially daughters including early detection of cancer as supporting and maintaining daughters' health in the family are parents' responsibilities including father.
\end{abstract}

Keywords: BSE, breast cancer, health knowledge, mothers, teenage women.

\section{INTRODUCTION}

The incidence of breast cancer increases every year worldwide including Indonesia. The International Agency for Research on Cancer in 2012 estimated that the percentage of new cases of breast cancer is $43.3 \%$ with a mortality rate of $12.9 \%$. Data from the Basic Health Research (2013) showed that breast cancer cases threatened 61,682 women in Indonesia. West Java, the province with the largest population in Indonesia, had the third highest position of breast cancer cases with 6,701 cases. One district in West Java, which is the City of Bandung reported that in the 2016-2017 period the number of breast cancer cases in this city doubled and 2.5\% of it was young women patients. Breast cancer threatens both adolescent and adult women. 
Breast cancer can be detected early by mammography, clinical breast examination, and breast self-examination (BSE) (Ministry of Health of Republic of Indonesia, 2016a). From those three early detection methods, BSE is considered an easy, and inexpensive method. It can be done by women themselves, and it is important to detect breast abnormalities early. $85 \%$ of breast cancer patients found breast changes after conducting BSE (Indonesian Ministry of Health, 2015).

Increasing incidence of breast cancer in adolescence indicates that young women should be aware of breast cancer, and willing to do early detection by doing BSE, especially after menstruation (Ministry of Health, 2015). Birhane et al., (2017) identified factors that influence young women in performing early detection including knowledge, awareness, and support of the closest person. According to Friedman (1998), the family is the closest person to adolescence, and one of its responsibility is to maintain and enhance the health of family members including daughters. The family member who had an important role in family health is the mother. Mother's support for family health, especially for her daughter according to (Sarafino, 2012) includes emotional support, by giving an understanding about the importance of health, supporting, and observing the daughter's health. Appraisal support is to provide motivation and provide rewards when children do something positive, including BSE. The third is instrumental support, namely by teaching girls how to do BSE and accompanying them in doing BSE. Lastly, information support is to provide information on the benefits of doing BSE, how to maintain breast health and nutritious food intake. These supports illustrate the significant roles of the mother in children health in particular daughter's health.

Mother's support is important to promote and maintain her daughter's health. One factor that influences parents in providing support for children's health is the level of parental knowledge about health (Febrianto, 2012). However, a limited study in Indonesia examines women's knowledge about BSE especially in mothers with teenage daughters. The purpose of this study was to assess knowledge about BSE among mothers with teenage daughters. 


\section{METHODS}

The design of this study was quantitative descriptive with 1 variable which is the level of women's knowledge. The population in this study was 138 women who had teenage daughters. The sample was selected using the total sampling technique. The number of samples was 138 women who had teenage daughters. The instrument in this study was a Knowledge questionnaire about BSE that had developed by Silaban et al., (2014). The instrument used to measure women's level of knowledge about BSE. There were 15 items of questions on the instrument and categorized using the Gutman scale. The knowledge questions component includes 2 questions about purposes and benefits of BSE, 3 questions about appropriate times for the BSE implementation, 9 questions about BSE steps, and 1 question about who has a role in conducting BSE. This knowledge instrument has been tested for validity with a range of values from 0.311 to 0.752 and the results of the reliability test using the Cronbach Alpha formula which is 0.842 .

The study was conducted in Sarijadi Village, Sukasari District, Bandung City. Sarijadi Village is part of the PHC Sarijadi work area. This sub-district consists of 4 villages, namely Geger Kalong, Isola, Sukarasa, and Sarijadi. This village consists of 11 RWs. The time of data collection was carried out in April - May 2018. The research ethics of the ethics committee of FK Unpad with letter number ethical 329 / UN6.KEP / EC / 2018.

\section{RESULTS}

\section{Characteristic of Respondent}

Table 1 Characteristic of Respondents $(n=138)$

\begin{tabular}{ccc}
\hline \multicolumn{1}{c}{ Characteristic } & Frequency (f) & Percentage (\%) \\
\hline Mothers' ages & & \\
$<45$ & 91 & 65.9 \\
$>45$ & 47 & 34.1 \\
Daughters' ages & & \\
$10-14$ & 78 & 56.5 \\
$15-20$ & 60 & 43.5 \\
\hline
\end{tabular}


Dewi Andriani: Knowledge of Breast Self-Examination among Women with Teenage Daughters

\begin{tabular}{lrr}
\hline Education & & \\
Elementary & 12 & 8.7 \\
Junior high school & 2 & 14.5 \\
Senior high school & 61 & 44.2 \\
University & 45 & 32.6 \\
& & \\
Occupation & & 75.4 \\
Housewives & 104 & 7.2 \\
Civil Servant & 10 & 10.1 \\
Employee & 14 & 7.2 \\
Self- employed & 10 & \\
Family income/month & & 37.7 \\
<2.600.000 & 52 & 62.3 \\
$>2.600 .000$ & 86 &
\end{tabular}

Family member with breast cancer

Yes

$\begin{array}{lrr}\text { No } & 6 & 4.3\end{array}$

$132 \quad 95.7$

BSE information sources

$\begin{array}{lll}\text { Electronic media } & 63 & 45.7\end{array}$

$\begin{array}{lrr}\text { Printing media } & 15 & 10.9\end{array}$

$\begin{array}{lrr}\text { Friends } & 2 & 1.4\end{array}$

$\begin{array}{lll}\text { Health professionals } & 38 & 27.5\end{array}$

Family $\quad 16 \quad 11.6$

$\begin{array}{lll}\text { Others } & 4 & 2.9\end{array}$

BSE experiences

$\begin{array}{lrr}\text { Yes } & 122 & 88.4\end{array}$

No $\quad 16 \quad 11.6$

Table 1 shows that the majority of respondents were <45 years old $(65.9 \%)$ and the majority of young women were between 10-14 years (56.5\%), the majority of respondents had attended senior high school (44.3\%), the majority of respondents worked as housewives (75.4\%), and family income per month> 2,600,000 (62.3\%). Almost all respondents did not have a family history of breast cancer. The source of information about BSE is $78(56.6 \%)$ parents learn about BSE from the media and more than half of the respondents have practiced BSE

Women's Knowledge of BSE

Table 2 Women's Knowledge of BSE 


\begin{tabular}{lrrrrrr}
\hline \multicolumn{1}{c}{ Sub-Variables of BSE Knowledge } & \multicolumn{2}{c}{ Good } & \multicolumn{2}{c}{ Moderate } & \multicolumn{2}{c}{ Poor } \\
& \multicolumn{1}{c}{ F } & \multicolumn{1}{c}{$\%$} & \multicolumn{1}{c}{ F } & \multicolumn{1}{c}{ \% } & \multicolumn{1}{c}{ F } \\
\hline Women's Knowledge & 58 & 42 & 71 & 51.4 & 9 & 6.5 \\
Purposes and benefits of BSE & 110 & 79.7 & 27 & 19.6 & 1 & 0.7 \\
Implementation time for BSE & 21 & 15.2 & 61 & 44.2 & 56 & 40.6 \\
BSE resources & 37 & 26.8 & 0 & 0 & 101 & 73.2 \\
Steps of BSE & 53 & 38.4 & 71 & 51.4 & 14 & 10.2 \\
\hline
\end{tabular}

Table 2 shows that the majority of respondents had a moderate level of knowledge. In this study respondents had good knowledge about the objectives and benefits of BSE, respondents had moderate knowledge about the time to do BSE and steps to conduct BSE, however respondents had poor knowledge about BSE resources, they confused who take a role in doing BSE for their daughters.

\section{DISCUSSION}

This study shows that more than half of the respondents had moderate knowledge of BSE. The criteria of good knowledge of BSE in this study were understanding the purposes and benefits of conducting BSE, the steps BSE, the time of BSE implementation, and the person who take a role in conducting BSE. There were respondents with good and poor knowledge levels of BSE. Moderate knowledge means women do not understand well about BSE in several focuses. This would have an impact on the support provided by women to their daughters in conducting BSE.

Studies on BSE knowledge has been carried out in Indonesia, but the most study subject were young women from different levels of education (Angrainy, 2017; Handayani \& Sudarmiati, 2012; Sulistyowati, 2017; Lubis, 2017; Seftiani, 2012). The results of those studies varied, the majority of young women had good and moderate knowledge of BSE, especially in research conducted at high schools or universities, little is known about mothers' knowledge of BSE. However, different results were identified in several studies outside Indonesia, according to Widiasih (2017) who did a literature review found that studies on ethnic minorities such as African immigrants in America identified low levels knowledge of cancer screening. Other factors also 
identified as influencing factors in health behavior cancer awareness including levels of education, age, insurance, income, and social culture.

The results of this study provide additional information about the knowledge of mothers who have daughters about BSE. Mother's knowledge is important to know because their knowledge would affect their behavior to daughters. Widiasih (2017) revealed that many descriptive quantitative studies in Indonesia confirmed the relationship between knowledge and behavior, especially women's health behavior. Aqni (2013) assessed delaying factors on cervical cancer screening. She found that knowledge, fear, family, and access to health services, were influenced women's behavior in cancer screenings. Yudiningsih (2015) revealed that knowledge greatly influences the implementation of family support. Parental support is proven to influence adolescents in conducting BSE (Puspita, 2016).

This study also found the types of information sources used by mothers when searching for BSE and breast cancer information. Most respondents preferred electronic media as the main source of health information. Health workers were not the main source of information for respondents in this study. Different results were identified in the literature review conducted by Widiasih (2017) who found that patient's health information sources were doctors, other health providers, friends, cancer patients, books, internet, TV, radio, and support groups. Information sought related to treatments, doctors and hospitals, schedules and services, and how to manage the side-effects of therapy. The media, especially the internet, is the main source of information in Indonesia in the industrial 4.0 era, including for women and their daughters. Indonesia is the sixth largest internet user in the world. Several positive effects of electronic media include helping in making decisions related to diagnosis, prevention and treatments, and enhancing women's knowledge about cancer. Electronic media sources are easy and cheap to access, however, people need to be careful with health information provided by media as not all information and knowledge available online is correct. Nurses as agents of change are expected to innovate in developing health education using electronic media especially information about women's health including early detection of cancer. The 
development of health education through the internet by nurses will help women, especially mothers, to get appropriate and accountable health information.

\section{CONCLUSION}

Limited health literacy is still a problem for women in Indonesia, the results of the study show that the majority of mothers have a moderate level of the BSE knowledge, only a few them have a good level of BSE knowledge, and there are mothers with poor knowledge of BSE. Mothers have a poor understanding of who takes a role in their daughters' BSE. Mentoring and coaching to mothers about BSE knowledge by health workers would help mothers in providing support and improving their roles in daughters' BSE. In addition, in this technology era, health workers, especially nurses, are required to develop innovative health education methods via the internet to help mothers and their daughters in obtaining appropriate health information including BSE. Further research is needed to examine the knowledge and roles of fathers in their daughters' health including early detection of cancer because supporting and maintaining children's health in the family is both parents' responsibilities including father.

\section{REFERENCES}

Birhane, K., Alemayehu, M., Anawte, B., Gebremariyam, G., Daniel, R., Addis, S., et al. (2017). Practices of Breast Self-Examination and Associated Factors among Female Debre Berhan University Students. International Journal of Breast Cancer. https://doi.org/10.1155/2017/8026297

Darmawan, R. A., Suzana, H., \& Setyorini, D. (2017). Gambaran Dukungan Keluarga Terhadap Kepatuhan Pengobatan pada Anak Usia Sekolah Penyandang Talasemia Mayor di Poli Talasemia RSUD Sumedang.

Febrianto, I. D. (2012). Hubungan Tingkat Penghasilan, Tingkat Pendidikan Dan Tingkat Pengetahuan Orangtua Tentang Makanan Bergizi Dengan Status Gizi Siswa Tk Islam Zahrotul Ulum Karangampel Indramayu. https://doi.org/10.1017/CBO9781107415324.004 
Dewi Andriani: Knowledge of Breast Self-Examination among Women with Teenage Daughters

Friedman, M. (1988). Keperawatan Keluarga: Teori dan Praktik. Jakarta: EGC.

Kemenkes RI. (2015). Peraturan Menteri Kesehatan Republik Indonesia Nomr 34 Tahun 2015: Penanglanan Kanker Payudara dan Kanker Leher Rahim, (706).

Kemenkes RI. (2016a). Bulan Peduli Kanker Payudara. InfoDATIN. https://doi.org/ISSN 2442-7659

Norviatin, D., \& Gustianty, E. R. (2017). Hubungan Tingkat Pengetahuan Women terhadap Minat Melakukan Pemeriksaan Payudara Sendiri di Wilayah Kerja Puskesmas Plumbon, (January), 21-24.

Notoatmodjo, S. (2007). Promosi Kesehatan \& Ilmu Perilaku. Jakarta: Rineka Cipta

Nur, N.R., Ermiati., \& Praptiwi, A. (2017). Motivasi Intrinsik Wanita Usia Subur (WUS) dalam Melakukan Pemeriksaan Payudara Sendiri (BSE) Di Kelurahan Kebonwaru Kota Bandung.

Pontoh, F., Kairupan, B.H.R., dan Sondakh, J. (2017). Hubungan Antara Pengetahuan, Sikap Serta Dukungan Keluarga dengan Tindakan Pemeriksaan Payudara Sendiri (BSE) pada Mahasiswi Semester II Akbid Makario Halmahera.Puspita, N. D. (2016). Faktor Yang Berhubungan dengan Perilaku BSE pada Mahasiswi Fakultas Non Kesehatan. Skripsi UNHAS.

Sarafino, E. P. (2012). Health Psychology: Biopsychosocial Interaction. John Wiley \& Sons Inc.

Septiani, S., \& Suara, M. (2013). Faktor - faktor yang Berhubungan dengan Perilaku Pemeriksaan Payudara Sendiri (BSE) pada Siswa SMAN 62 Jakarta. Jurnal Ilmiah Kesehatan, V(1), 2.

Silaban, E. R., Solehatti, T., \& Yani, D. I. (2014). Gambaran Pengetahuan, Sikap, dan Tindakan Wanita Usia Subur Tentang Pemeriksaan Payudara Sendiri (BSE) di Puskesmas Jatinangor, Sumedang. Skripsi tidak dipublikasikan.

Sinaga, C. F., \& Ardayani, T. (2016). Hubungan Pengetahuan dan Sikap Remaja Putri Tentang Deteksi Dini Kanker Payudara Melalui Periksa Payudara Sendiri Di SMA Pasundan 8 Bandung Tahun 2016. Kartika-Jurnal Ilmiah Farmasi, 4(1), 16-19. 
Dewi Andriani: Knowledge of Breast Self-Examination among Women with Teenage Daughters

Wulansari, G.M., dan Puspita, D. (2017). Faktor-Faktor Yang Berhubungan dengan Perilaku BSE pada Mahasiswi PSIK UMY.

Yudiningsih, N. (2015). Faktor-Faktor yang Mempengaruhi Pelaksanaan Dukungan Keluarga pada Penderita Hipertensi di Puskesmas Pancur Rembang. 